F. med. Genet. (1966). 3, I94.

\title{
Homocystinuria
}

\section{An Observation on the Inheritance of Cystathionine Synthase Deficiency}

\author{
GERALD GAULL* and M. K. GAITONDE
}

From the Neuropsychiatric Research Unit, Medical Research Council Laboratories, Carshalton, England, and t $\mathrm{\omega}_{\mathrm{G}}$ Division of Pediatric Neurology, Columbia-Presbyterian Medical Center, New York, U.S.A.

Homocystinuria is an inborn error of the metabolism of methionine, which is associated with a deficiency of cystathionine synthase activity in liver and brain. It is inherited as an autosomal recessive trait; characteristic clinical stigmata usually include mental retardation and ectopia lentis (Carson, Dent, Field, and Gaull, 1965; Schimke, McKusick, Huang, and Pollack, 1965; Mudd, Finkelstein, Irreverre, and Laster, 1964; Brenton, Cusworth, and Gaull, 1965a, b).

Incipient glaucoma secondary to complete dislocation of the optic lens necessitated operative removal of the lens in a patient. It seemed of genetic interest, therefore, to examine this tissue for evidence of cystathionine synthase activity. The lens is of special interest since it is derived embryologically from superficial ectoderm which is induced by the optic vesicle of the neural ectoderm.

\section{Methods}

The lens from this 7-year-old patient with homocystinuria (Case 5 of Carson et al., 1965) was removed at operation intact, and placed immediately in ice-cold physiological saline for transport to the laboratory. It weighed $123 \mathrm{mg}$., was crystal clear, but was spherical rather than typically lens-shaped. It was incubated with shaking in air for four hours at $36 \cdot 7^{\circ} \mathrm{C}$. in a flask containing ro $\mathrm{ml}$. Krebs-Ringer phosphate solution with I mg. per ml. glucose plus $9 \mu \mathrm{c}$ of ${ }^{35} \mathrm{~S} \mathrm{~L}$-methionine, $\dagger$ containing $0.2 \mu$ moles of L-methionine in $0.2 \mathrm{ml} . \mathrm{H}_{2} \mathrm{O}$ (specific activity $=45 \mathrm{mc} / \mathrm{mM}$ ). Paper chromatography of $100 \mu$ l. radioactive methionine solution revealed no other ninhydrin-positive material (isobutanol: $90 \%$ formic acid: $\mathrm{H}_{2} \mathrm{O}, 75: 15: 10, \mathrm{v} / \mathrm{v}$ ). As control, a

Received April 4, 1966.

* Recipient of a Special Fellowship from the National Institute of Neurological Diseases and Blindness, United States Public Health Service.

† Obtained from the Radiochemical Centre, Amersham. normal lens was similarly incubated on another day. $\Phi$ was obtained at operation from a 50-year-old man who underwent enucleation because of a tumour of the reting This lens weighed $228 \mathrm{mg}$. and was clear. In contrast fo the lens from the patient with homocystinuria, it wos typically lens-shaped. At the end of the incubation period the lenses, still intact, were homogenized ice-cold $6 \%$ perchloric acid and separated into a protein fraction and an acid-soluble fraction. After this, operations were carried out in parallel.

Protein Fraction. The protein fraction was washed four times with ice-cold perchloric acid followed by two washings of acetone, two washings of chloroforn methanol $2: 1$, and finally two washings of ether. T dried protein was hydrolysed in $6 \mathrm{ml}$. $6 \mathrm{~N}$ hydrochlor?e acid in sealed tubes overnight, and the acid was removed by evaporation under reduced pressure. The hydrolysate was then oxidized for two hours with performic acid which was similarly removed. This was transferred a column of Dowex I CO $=(0.9 \times 15 \mathrm{~cm}$. 200-400 mesh, X ro). After washing with $50 \mathrm{ml}$. water, $100 \mathrm{~m}$. o. I N acetic acid were put over the column, convertifg it to the acetate form and giving a neutral eluate coot taining methionine sulphone. This was followed $100 \mathrm{ml} .0 \cdot \mathrm{I} \mathrm{N}$ hydrochloric acid, giving an intermediage acetate eluate, and, finally, an acidic eluate containimg cysteic acid was collected at the stage when excess free $\mathrm{HCl}$ emerged from the column. The eluates containing methionine sulphone and cysteic acid were evaporated to dryness, made up to volume, and an aliquot trans:ferred to Whatman No. I filter paper. The neut eluate was developed in two directions: first, butangl acetic acid-water $(4: \mathrm{I}: 5, \mathrm{v} / \mathrm{v})$ for 40 hours, followel by acetone-water $(4: I, v / v)$ for 12 hours. The acidic eluate was developed only in the first direction. T但 chromatograms were sprayed with $0.5 \%$ ninhydrin in methanol $(p \mathrm{H} 5.0)$ and methionine sulphone and cysteffc acid spots eluted with $60 \%$ ethanol. The optical densigy of the solution was measured at $570 \mathrm{~m} \mu$ and the amounts of amino acids calculated from the optical densities $\mathrm{g}^{\mathrm{f}}$ the known amounts of these amino acids run under the same conditions. The radioactivity was determined on 
the same solution by liquid scintillation counting in Bray's solution (Bray, 1960) at $60 \%$ efficiency.

Acid-soluble Fraction. After neutralization with $\mathrm{KOH}$ and removal of the potassium perchlorate precipitate, the acid-soluble fraction was transferred quantitatively to Dowex $2 \mathrm{Cl}^{-}(0.9 \times 15 \mathrm{~cm}$., 200-400 mesh, X 10). The column was then washed with $50 \mathrm{ml}$. water, and the wash was evaporated to near dryness and transferred quantitatively to a similar Dowex I $\mathrm{CO}_{3}^{=}$. This column was washed with $50 \mathrm{ml}$. water. The column was then eluted with $100 \mathrm{ml}$. $0.1 \mathrm{~N}$ acetic acid, giving a neutral eluate containing the free sulphur amino acids. Oxidation by performic acid was performed after, rather than before, this fraction was collected. The neutral fraction then underwent two-dimensional paper chromatography as described except that $10 \mu \mathrm{g}$. each of the appropriate amino acids were added at the origin as carrier. The column was further eluted with $100 \mathrm{ml}$. $0.1 \mathrm{~N} \mathrm{HCl}$ in the same manner as the protein hydrolysate. Since the oxidation was performed after collection of the neutral fraction, cyst(e)ine appeared in the neutral fraction and then was converted to cysteic acid. Therefore, it did not appear in the acid fraction as it did in the protein hydrolysate. The acetate and acid fractions contained insignificant amounts of radioactivity and were nct further studied.

\section{Results}

Labelled methionine and cyst(e)ine were incorporated into the proteins in both lenses. Under these conditions, the specific radioactivities of the cysteine and methionine in the proteins of the lens of the patient with homocystinuria were the same as those of the patient with a normal lens (Table I). This suggested that the conversion of methionine to cysteine in the lens of the patient with homocystinuria was unimpaired. Direct confirmation of this was sought in the acid-soluble fraction.

A pilot experiment with a cataractous lens had shown that the amounts of the sulphur-containing free amino acids in the acid-soluble neutral fraction were too small to be detected chemically by these methods. Thus, because of the rarity and small size of the specimens, it was deemed prudent to add carrier amino acids to the paper chromatograms and to determine total radioactivity of the various compounds rather than specific activities. This seemed justified in view of the very small pool sizes involved. Since the unique opportunity to do the experiments arose suddenly and at a time when our assessment of the recoveries of radioactivity from the various fractions by this new method was incomplete, a tally of all the counts into the various acid-soluble sub-fractions was done, to be certain that the results in the two lenses were comparable. The results
TABLE I

INCORPORATION OF ${ }^{\text {ss }}$ FROM METHIONINE INTO LENS PROTEIN

\begin{tabular}{l|c|c}
\hline & Control & Homocystinuric \\
\hline Methionine & 6605 & 6278 \\
Cyst(e)ine & 232 & 406 \\
& & \\
\hline
\end{tabular}

The data give specific activity: counts $=$-er minute per $\mu$ mole

TABLE II

DISTRIBUTION OF RADIOACTIVITY INTO VARIOUS LENS ACID-SOLUBLE SUB-FRACTIONS

\begin{tabular}{c|r|r}
\hline \multicolumn{1}{c|}{ Sub-fraction } & \multicolumn{1}{c|}{ Control } & Homocystinuric \\
\hline Dowex I effluent & $90,825(18 \%)$ & $18,809(16 \%)$ \\
Dowex I neutral eluate & $393,730(79 \%)$ & $97,022(81 \%)$ \\
Dowex I intermediate eluate & $5,249(1 \%)$ & $1,921(2 \%)$ \\
Dowex I acidic eluate & $6,937(1 \%)$ & $2,668(1 \%)$ \\
\hline \multicolumn{1}{c|}{ Total } & 497,741 & 120,420 \\
\hline
\end{tabular}

The data give counts per minute and percentage distribution of radioactivity in the acid-soluble fraction.

(Table II) demonstrated that the distribution of radioactivity in the various sub-fractions was similar. The major portion of the radioactivity appeared in the neutral eluate which contained the neutral sulphur-containing amino acids. The percentage of the acid-soluble fraction contained in the neutral eluate was approximately $80 \%$ in each lens. The other sub-fraction containing a significant portion of the radioactivity was the effluent which contained about $17 \%$ of the total radioactivity in each lens. Evidence will be presented elsewhere showing that a considerable amount of the radioactivity appearing in the Dowex $\mathrm{CO}_{3}$ effluent represents $\mathrm{S}$-adenosylmethionine ('active methionine').

An estimate of the conversion of the immediate precursor homocysteine into its product cystathionine and the next product cysteine was determined by comparing the total counts in each of the products with the total counts in the precursor. This comparison showed that, under the conditions of the experiment, the ability to convert homocysteine to cystathionine and cysteine in the acid-soluble fraction was the same in the lens from the patient with homocystinuria as in the control lens (Table III). Similar comparisons with regard to methionine and taurine could not be calculated because these two are the fastest running constituents in the second direction, and due to an error they ran to the 
edge of the paper and were partially lost. This is one of the many factors that contributed to losses of ${ }^{35} S$ after paper chromatography (cf. Tables II and III).

\section{TABLE III}

INCORPORATION OF ${ }^{35}$ S FROM METHIONINE INTO LENS ACID-SOLUBLE FRACTION

\begin{tabular}{|c|c|c|c|c|c|}
\hline & $\begin{array}{l}\text { Homo- } \\
\text { cysteine }\end{array}$ & $\begin{array}{l}\text { Cysta- } \\
\text { thionine }\end{array}$ & Cysteine & $\begin{array}{l}\text { Cysta- } \\
\text { thionine/ } \\
\text { Homo- } \\
\text { cysteine }\end{array}$ & $\begin{array}{c}\text { Cysteine/ } \\
\text { Homo- } \\
\text { cysteine }\end{array}$ \\
\hline $\begin{array}{l}\text { Control } \\
\text { Homocystinuric }\end{array}$ & $\begin{array}{r}26,769 \\
7738\end{array}$ & $\begin{array}{r}1725 \\
719\end{array}$ & $\begin{array}{r}1800 \\
675\end{array}$ & $\begin{array}{l}0.06 \\
0.09\end{array}$ & $\begin{array}{l}0.07 \\
0.09\end{array}$ \\
\hline
\end{tabular}

The data give counts per minute.

\section{Discussion}

Cystathionine synthase activity had been shown previously to be deficient in the liver and brain of patients with homocystinuria (Mudd et al., 1964; Brenton et al., 1965a, b). Under the conditions of these experiments, the activity of cystathionine synthase was found to be present to an equal extent in the lens from a patient with homocystinuria as compared to a control lens. These results suggest that either a structural gene controlling the development of cystathionine synthase, or a regulator gene controlling its synthesis or inactivation, is different in the lens from the corresponding genes in liver and brain.

Well-studied instances of multiplicity of gene control of an enzyme activity are few. In the hereditary myopathy due to deficiency of muscle phosphorylase, the liver phosphorylase is normal, whereas in the hereditary deficiency of liver phosphorylase, the muscle phosphorylase is normal (Rowland, Fahn, and Schotland, 1963). These two enzymes show a number of clear differences in properties of inactivation and reactivation so that this would seem to be an instance of distinct enzymes produced under the influence of different genes. Another apparent instance of the multiplicity of gene control is the inheritance of glucose-6phosphate dehydrogenase deficiency in which the deficiency exhibited by the erythrocytes may or may not be accompanied by a similar deficiency in the leucocytes; here as well, present evidence favours molecular heterogenecity (Marks, 1964). Since the number of enzymes examined for such tissue differences is small, it is not possible to say whether this multiplicity of gene control is general or exceptional. The comparative properties of cysta- thionine synthase in various tissues should $\overrightarrow{\mathrm{B}}_{e}$ explored, especially with regard to possibte differences in isoenzyme subunits.

It is of embryological interest that the lens, which differentiates later than the brain but by induction of the superficial ectoderm by the optic vesicle of the developing brain, should exhibit such difference in enzyme phenotypy.

Comparison of the radioactivity (counts $/ \mathrm{min}$.) in acid-soluble fraction of the lens from the homor cystinuric patient with that of the control le $\overrightarrow{\mathrm{gs}}$ indicated that the latter incorporated three to fos? times as much radioactivity as the former. This not entirely unexpected in that the control lens was larger and therefore had more actively metabolizirig cells. Furthermore, it is known that the intracellul pool of methionine in the erythrocytes of these patients is larger, reflecting the raised concentration of methionine in the plasma (unpublished results of Dr. G. Winston Barber, Wills Eye Hospitad, Philadelphia, Pennsylvania). Since the lens known to transport amino acids actively from the surrounding aqueous humour (Kinsey and Redd\% 1963), it seems likely that the smaller total amount of radioactivity entering the lens is a reflection a relatively large pool of unlabelled methionine $\mathbb{R}$ the lens. Although the plasma methionine level 2 the time of operation was not determined, th: patient (G. McC.; Brenton et al., I965a, b) wकु known to run raised methionine levels.

This potentially larger pool of unlabelleg methionine may also account for the similarity of the incorporation of ${ }^{35} \mathrm{~S}$ into methionine an cyst(e)ine of protein. In the lens from the child, as compared to the older adult, a larger protem incorporation would have been anticipated (persona: communication, Dr. Abraham Spector, Institute 8 f Ophthalmology, New York). In any case, this would be consistent with the early cataracts known occur in these patients (Carson et al., 1965).

Certain tacit assumptions deserve commen First, it is assumed that the trans-sulphuration pathway remains active in the ageing lens, since is might be argued that had a control lens from younger patient been used, the cystathionine syns thase activity might have been greatly reduced. N8 firm information is available on this point, but the similar distribution of radioactivity in the various sub-fractions (Table II) tends to support the ide that the pathway is active. Secondly, this expert ment assumed that no alternative pathways for the conversion of methionine to cystathionine and cysteine existed in the lens. This seems likely ot present knowledge but cannot be ruled out un equivocally. Finally, steady-state kinetics weres 
assumed. Since this was a tracer experiment, the question of saturation of the enzyme by substrate was not relevant. In any case it seems likely that substrate was not rate-limiting, since the incubation medium was sampled periodically during the incúbations, and it was determined that the net utilization of substrate was less than the error of direct scintillation counting of the media. Had substrate been rate-limiting in this system, it would seem likely that a four-hour incubation would have largely depleted it, since it is known that methionine is actively taken up by lens (Mandel, Dardenne, and Lessinger, 1957) and has the highest affinity for the active transport sites of neutral amino acids in lens (Kinsey and Reddy, 1963). Simply adding a greater concentration of unlabelled methionine to the incubation medium would not be definitive, since with surviving lens, the uptake of tracer amino acid decreases asymptotically with the total concentration of amino acids present in the surrounding media.

\section{Summary}

Cystathionine synthase activity, previously shown to be absent from liver and brain of patients with homocystinuria, was found to be present in the optic lens of such a patient. The biological implications are discussed briefly.

The authors wish to express their appreciation to Dr. Derek Richter for his helpful comments; to Dr.
Claude Field and Mr. Eric Cowan of the Belfast City Hospital who cared for the patient with homocystinuria; to Mr. Alan Friedman and the staff of the Royal Eye Hospital, London, who arranged to obtain the control lens; and to Dr. G. Winston Barber of the Wills Eye Hospital, Philadelphia, and Dr. Abraham Spector of the Institute of Ophthalmology, New York, both of whom read the manuscript critically.

\section{REFERENCES}

Bray, G. A. (1960). A simple efficient liquid scintillator for counting aqueous solutions in a liquid scintillation counter. Analyt. Biochem., I, 279.

Brenton, D. P., Cusworth, D. C., and Gaull, G. E. (1965a). Homocystinuria. Biochemical studies of tissues including a comparison with cystathioninuria. Pediatrics. 35, 50.

- , and - (1965b). Homocystinuria: metabolic studies on 3 patients. F. Pediat., 67, 58.

Carson, N. A. J., Dent, C. E., Field, C. M. B., and Gaull, G. E. (1965). Homocystinuria: clinical and pathological review of ten cases. ibid., 66, 565 .

Kinsey, V. E., and Reddy, D. V. N. (1963). Studies on the crystalline lens X. Transport of amino acids. Invest. Ophthal., 2, 229.

Mandel, P., Dardenne, U., and Lessinger, A. (1957). Incorporation et dégradation de la méthionine par le cristallinde bovidés. C.R. Acad. Sci. (Paris), 245, 985.

Marks, P. A. (1964). Glucose-6-phosphate dehydrogenase: its properties and role in mature erythrocytes. In The Red Blood Cell, ed. C. Bishop and D. Surgenor, p. 21 I. Academic Press, New York.

Mudd, S. H., Finkelstein, J. D., Irreverre, F., and Laster, L. (1964). Homocystinuria: an enzymatic defect. Science, 143, 1443.

Rowland, L. P., Fahn, S., and Schotland, D. L. (1963). McArdle's disease. Hereditary myopathy due to absence of muscle phosphorylase. Arch. Neurol. (Chic.), 9, 325.

Schimke, R. N., McKusick, V. A., Huang, T., and Pollack, A. D. (1965). Homocystinuria: studies of 20 families with 38 affected members. F. Amer. med. Ass., 193, 71 I. 